\title{
Perspectives on the Reception of Immigrants in the Catalan Cross-Border Area (Franco-Spanish Border)
}

\author{
Eliseu Carbonell Universitat de Girona (Spain) \\ Xavier Casademont Universitat de Girona (Spain) \\ Josep-Miquel Palaudàrias Universitat de Girona (Spain) \\ Gautier Sabrià Institut Regional del Treball Social de Perpinyà (France)
}

\begin{abstract}
This article is based on ethnographic research in a cross-border region of Mediterranean Europe distributed between the French and Spanish states. Specifically, these are two neighbouring regions, with a shared historical past, where the presence of migrants crossing the border from south to north or arriving from other points of origin has initiated deployment of welcoming actions by humanitarian organisations and local administrations. However, these actions are in stark contrast to the very restrictive migration policies of the two states. The article explores the perspective of the agents who work in these organisations and how their work relates to the increasingly hostile climate, which is a result of the migration policies currently implemented by European states.
\end{abstract}

Keywords: immigration, welcoming, borders, Catalonia, NGOs

Résumé : Cet article a été élaboré à partir d'une recherche ethnographique menée dans une région transfrontalière de l'Europe méditerranéenne située entre les États français et espagnol. Cette zone frontalière située entre deux régions voisines qui partagent un passé commun est traversée par de nombreux migrants du sud vers le nord, ou en provenance d'autres lieux, ce qui a déclenché la mise en place de mesures d'accueil par des organisations humanitaires et des administrations locales. Ces actions contrastent néanmoins avec les politiques de ces deux États très strictes en matière de migration. Cet article aborde les points de vue des travailleurs de ces organisations quant aux activités de leur propre organisation et à la détérioration de la situation d'accueil en raison des politiques de migration qui sont actuellement mises en application par les États européens.

Mots-clés : immigration, accueil, frontières, Catalogne, ONG

176 / Eliseu Carbonell et al.

\section{Introduction}

7 his article proposes a comparative study between

$\mathcal{1}$ two territories on the Franco-Spanish border that historically have been part of Catalonia. This cross-border geographic area is recognised by the $\mathrm{EU}$ as a $\mathrm{Eu}-$ rodistrict (Eurodistrict of the Catalan Cross-Border Area), ${ }^{1}$ whose objective is to collaborate and improve administrative relations on both sides of the border. In accordance with EU treaties and in particular the Schengen Agreement, in migratory terms, the EU should function as a zone without internal borders. However, the reality is that, with regard to migrants, despite their theoretically being able to travel across the border between France and Spain (although on the French side, police controls on the entry road to the country have become increasingly frequent within a few kilometres of the border), the situation regarding the reception of foreign citizens differs depending on whether they arrive in Perpignan (FR) or Figueres (ESP) - the two main cities of this cross-border area, located just 30 kilometres from their respective border points.

The current Franco-Spanish border (on the Mediterranean side), delineated by the Treaty of the Pyrenees of 1659, separates the historical territory of Catalonia in two. The Catalan counties of Roussillon, Conflent, Vallespir, Capcir and Alta Cerdanya are situated within the French state, with the official name Département des Pyrénées Orientales (Department of the Eastern Pyrenees), and the rest, to the south of the border, lie within Spain, with the official name Comunitat Autònoma de Catalunya (Autonomous Community of Catalonia). From a Catalan historical perspective, these territories are known as Northern Catalonia and the Principality of Catalonia or simply the Principality, respectively. In this article we will use the historical denominations to distinguish the two territories. It is, therefore, a cross-border region with a geographical, 
linguistic and cultural continuity, as well as numerous social and economic ties throughout modern history, regardless of the division into two states (Alland and Alland 2006).

Nevertheless, despite this geographical and cultural continuity, and despite the fact that within the European Union there is a certain consensus on migration policy, both the French and Spanish states have their own legislation on immigration. This significantly affects the way in which local agents put into practice the welcoming of migrants. Taking into account the historical and social antecedents on migration into each of these territories on one side and the other of the border, this article investigates the significance of the reception of the migrant population by humanitarian organisations that work in the immigration sector carrying out welcoming tasks. This is done by studying the practice of welcoming through the reflections of the agents who intervene in this process.

In summary, we observe in southern Europe a border territory that divides a historical region with a common language and culture, and with social exchanges that have been maintained over time, but where the weight of state policies is a determining factor in multiple aspects and has ended up configuring two differentiated societies. One of these differences, as will be seen, is the way in which the reception of the population of migrant origin is understood and how it is carried out by the welcoming agents themselves. The focus of this article, therefore, is not so much the migrant population, but the receiving population and how it welcomes migrants. The migratory phenomenon has had many effects on the societies of southern Europe. There is often talk of the emergence of xenophobia in populist and far-right political parties (Crépon, Dézé and Mayer 2015; D’Appollonia 2007; Lazaridis and Veikou 2017; Thorleifsson 2017). Yet, we must also talk about the emergence of networks of welcoming and solidarity (Knott 2018) and the way in which these understand the integration of the migrant population, which, as we shall see, sways between assimilation and inclusion.

\section{Welcoming and Integration Policies}

Population movements at the international level are conditioned by policies governing immigration, integration and asylum that countries apply when migrants cross their borders. These policies vary within the European Union, but have in common the fact that they have become stricter over time and with the increase in migratory flows throughout the world (Düvell 2011; Enríquez
2009; Julien-Laferrière 2016; Khosravi 2007; Pécoud and Guchteneire 2011; Samers 2004; Veron 2013). Several European countries have abandoned and/or widely questioned the multicultural policies that were more or less dominant in the past (Joppke 2017; Vertovec and Wessendorf 2010) and have adopted policies that are increasingly based on control and assimilation (Gehring 2013; Lauth Bacas 2013; Stolcke 1995; Spijkerboer, 2007). These policies of control are being implemented in a context of globalisation dominated by neoliberal policies. They are simultaneously the cause and effect of migrations and of "migratory protectionism" (Bacon 2008; Bernard 2002; Brown 2010), which aims to restrict the freedom of movement of people whose objective is to achieve the human rights they are denied (Naïr 2007). As Kabunda $(2012,17)$ says, "the North seeks to export or extend [this protectionism] on a planetary scale. The result is the proliferation of irregular or clandestine migration."

In this context, the situation of migrants and refugees at borders is, as is often exposed by the media and denounced by the NGOs that welcome them, a complex and conflictive situation because of the conditions of exclusion they are subject to. This complexity is not being addressed with sufficient knowledge or resources or, above all, the necessary humanity on the part of the society that should be welcoming them.

In light of the above, reception mechanisms are a crucial factor that can mark the subsequent integration of migrants into the receiving society. Welcoming is a component of the process of adaptation of newcomers and is the first step toward inclusion (Back and Sinha 2012; Frozzini and Law 2017; Regnault, Racine and Breugnot 2018). Welcoming provides the option to establish positive neighbourly relations, provide responses regarding the rights of migrants, offer guidance on the myriad questions posed by newcomers, and give them the opportunity to acquire the knowledge and skills they need at this stage of their migration project.

In the welcoming process, we must consider the normative and social mechanisms that the administration makes available to newcomers - mechanisms that have suffered significant cutbacks in the social aspect in recent years, despite increased vulnerability among the migrant population (Frozzini and Gratton 2015). In welcoming, the first space of attention and support is often formed by people from the migrants' country of origin who are now somewhat settled and who, to some extent, have managed to create, with more or less precariousness, a support network. In parallel, humanitarian 
organisations formed by Indigenous volunteers and/ or professionals are also present. In addition, in recent years, several institutions, especially local authorities, have promoted welcoming strategies from the local sphere, as well as creating networks of cities committed to the reception of immigrants.

Unlike other concepts with a long tradition in migration studies that have been used to describe the arrival and installation of a migrant population in a given territory (whether a city, region or state), including integration, exclusion and inclusion, the concept of "welcoming" has been little developed from a theoretical point of view. Some authors have preferred to use the concept "welcomeness," defining these practices as those that treat people equally regardless of their status. According to this perspective, the differences in the way immigrants are welcomed are key, because "variations in the degree of welcomeness of local agencies toward immigrants may affect immigrants' perceptions of government and their place in society" (Williams 2015, 435). Other scholars use the expression "reception policies," meaning "policies pertaining to welcoming newcomers and giving them tools to participate in mainstream society, language integration, cultural adaptation, education, and social services for immigrants" (Zapata and Barker 2014, 32). From their point of view, reception policies are more amenable to power-sharing between different tiers of government.

The greatest amount of work on the concept of welcoming has been done in the study of reception policies. Its conceptualisation there has been more empirical, rather than the result of a theoretical debate between academics. A recent example of how the term "welcoming" has been conceptualised is found in the work of Esses et al. (2010). After analysing documentation from government reports and community documents, as well as scholarly literature, they conclude that there are 17 characteristics ${ }^{2}$ that enable us to evaluate the degree to which a community is welcoming to newcomers and promotes immigrant attachment and belonging (see also George et al. 2017, 31). The main international examples are situated in Canada (Wiginton 2013), where for many years there has been an interest in studying how communities are concerned about attracting and welcoming immigrants. More recently, studies have been conducted that evaluate specific welcoming initiatives in the United States (Huang and Yang Liu 2018; Williamson 2018) and Canada (George and Selimos 2018; George et al. 2017).

As a result of this interest, reference is often made to the "welcoming community," which is described based on its spatial and discursive dimensions. A welcoming community spatially denotes "a town, city or region in which newcomers feel valued and their needs are served" (Esses et al. 2010, 9). The latter dimension refers to the host society's articulation of a discourse in which it assumes responsibility for the settlement process: "a community having agency and engaging in actions that facilitate the integration of newcomers" (Esses et al. 2010, 9). From this perspective, a community should seek not only to receive immigrants, but also to welcome them; not only must they attract them, but they must retain them (National Working Group on Small Centre Strategies 2007). Thus, a welcoming community has been defined as a place where there is a "strong desire to receive newcomers and to create an environment in which they will feel at home" (National Working Group on Small Centre Strategies 2007, 94). It can be conceptualised as a collective effort to create a place where individuals feel valued and included (Esses et al. 2010). The importance of establishing links between the main actors working with the welcoming communities and the presence of newcomer-serving agencies (Burr 2011) is also highlighted. However, some authors, based on the study of specific cases, have warned about the lack of evidence of a firm political commitment in this respect (Derwin and Krahn 2008).

Thus, welcoming policies are part of integration processes; however, it is important to show the intersections between these two concepts. Many scholars have highlighted the contested nature of "integration." It has different meanings that are sometimes completely contradictory, resulting in a chaotic concept that distorts reality (Wieviorka 2014). Thus, it is accepted, but in part because of the lack of more satisfying alternatives (Spencer 2011). In this paper we assume a notion of integration that conceives it as a complex, dynamic process - involving not only newcomers, but also natives. Mainly, these processes take place in the structural, social, cultural, civic and political, and identity domains (Ager and Strang 2008; Garcés and Pennix 2016; Heckmann 2006; Spencer and Charsley 2016). Even though many of these scholars fail to include welcoming policies as occurring within these domains, it will be shown later that the cases analysed include welcoming initiatives as an initial part of integration processes.

\section{Methodology}

The most intensive part of the fieldwork for the present study was conducted between July and December 2017. It consisted of in-depth interviews with 26 informants belonging to organisations that carry out welcoming functions for migrant population, as detailed in Table 1. Prior to these dates, preparatory meetings were held with public administration officials in charge of migrant 
reception and inclusion programs. At the end of the interview phase, a workshop was organised in which a majority of the interviewees, plus other members of their organisations - altogether 40 people - participated, separated into two focus groups to identify the main problems and challenges faced by individuals who work in organisations that carry out welcoming tasks on both sides of the border. Finally, it is worth mentioning that during fieldwork, in addition to the interviews, participant observation was employed in the waiting rooms of organisations to examine the interaction between users and volunteers/workers of the organisations, as well as in the assembly of the Collectif sans papiers de Perpignan (a support group for undocumented immigrants).

Regarding the typology of informants, we can distinguish three types: (1) employees, (2) volunteers and (3) activists. Organisations can be grouped into four types: (1) organisations (NGOs) of a religious nature with many years of history and international implantation; (2) local-level organisations (NGOs) created in the last few years by immigrants from a specific country or region of the world; (3) leftist political organisations and trade unions with a long tradition of involvement in social struggles; and (4) grassroots organisations that depend on local administrations. The first type of organisation is formed by a combination of employees and volunteers in different proportions depending on the organisation, but generally their actions are supported by a large contingent of volunteers. Organisations pertaining to the second type are entirely staffed by volunteers, without employees, whereas organisations in the third group are made of up individuals who define themselves as activists rather than volunteers. These organisations do not have employees dedicated to welcoming tasks in a specific way, and they are found only in Northern Catalonia. The fourth type, due to a legislative singularity (Law 10/2010, see below), exists only in the Principality of Catalonia, where local administrations are also involved in welcoming through specific offices staffed by intercultural mediators and other professionals with specific training. Table 1 shows the complete list of informants, indicating gender, approximate age, nationality, time spent working in the organisation - fewer than five years $(<5)$, between five and ten $(5-10)$, or more than ten $(>10)-$ whether they are a volunteer, employee or activist, the organisation to which they belong and the city or town where the interview was conducted.

\section{Migrations and Control Zone in Northern Catalonia}

When the issue of migratory flows in the Catalan cross-border area is addressed, a moment of historic magnitude in the twentieth century stands out: the Retreat. Between January and February 1939, toward the end of the Spanish Civil War, it is estimated that 480,000 people crossed the Catalan border to enter the Département des Pyrénées Orientales - which had 233,347 inhabitants in 1936. Of this migratory flow, 350,000 people would be interned in concentration camps in Northern Catalonia as of February 1939, among other reasons because of their "suspicious" profile in relation to their tacit radical political ideas (Tuban 2018). The Retreat would have repercussions on the demography of the territory, as many refugees remained permanently in Northern Catalonia. Thus, in 1946, 72.3\% of foreigners living in Northern Catalonia region were Spanish citizens (Dukic 2009).

In the 1960 s, this territory again faced another form of non-transnational migration stemming from the independence of Algeria, which had previously been a French department. In 1962 and after the independence of Algeria, 30,000 "European returnees" arrived in the Northern Catalonia, and half settled in Perpignan (Bouba 2009). However, these "returnees," also called Pieds-Noirs (black feet), were not the only people to leave Algeria after its independence. The Harkis - Algerians who fought on the French side - also returned to this part of France, despite not receiving the same treatment from its institutions. With the arrival of the Harkis, Northern Catalonia returned to its role as a "retention zone," as they were sent to Camp Joffre in Rivesaltes (Moumen 2010). After having retained Spanish refugees, this camp was used for Jews during the German occupation period, and would later "welcome" about 12,000 Harkis (Lebourg 2011). The Département des Pyrénées Orientale became a staging area of foreign populations of the French state. While Northern Catalonia would receive various migrations throughout the twentieth century, not all would receive the same treatment: the foreign populations would be locked in camps, whereas an inclusive welcome would be promoted for the "repatriated" French.

In the twenty-first century, Northern Catalonia, thanks to its cross-border nature, remains a transit area for migrants, although in the French state the question of the reception of migrants has crystallised not around the Northern Catalan territory but in the far north of the country, in Calais. The French centralist system does not allow for compilation of clear data on the number of people crossing the Catalan border illegally. Jean René Augé (2018), former chief of service at the Police aux Airs et aux Frontières (PAF) of the Département des Pyrénées Orientales, suggests that about 4,500 have been questioned by the PAF and a thousand have been expelled. ${ }^{4}$ 
Table 1. Informants participating in the research

\begin{tabular}{|c|c|c|c|c|c|}
\hline Informant & Nationality & Time & Position & Organisation & City/town \\
\hline Woman, 25 & Spain & $<5$ & Employee & Red Cross & La Jonquera (ESP) \\
\hline Woman, 55 & Spain & $5-10$ & Employee & Red Cross & La Jonquera (ESP) \\
\hline Man, 40 & Morocco & $<5$ & Volunteer & Islamic Center & L'Escala (ESP) \\
\hline Man, 55 & Honduras & $<5$ & Volunteer & Association of Hondurans & Figueres (ESP) \\
\hline Man, 25 & Morocco & $5-10$ & Volunteer & Network for coexistence & Roses (ESP) \\
\hline Woman, 45 & Spain & $<5$ & Employee & Caritas & L'Escala (ESP) \\
\hline Woman, 70 & Spain & $>10$ & Volunteer & Caritas & L'Escala (ESP) \\
\hline Woman, 50 & Spain & $<5$ & Employee & Caritas & Figueres (ESP) \\
\hline Man, 75 & Spain & $>10$ & Volunteer & Caritas & Figueres (ESP) \\
\hline Woman, 40 & Peru & $5-10$ & Employee & Caritas & Girona (ESP) \\
\hline Woman, 35 & Morocco & $5-10$ & Employee & Social Welfare Area & Figueres (ESP) \\
\hline Man, 45 & Morocco & $5-10$ & Employee & Social Welfare Area & Figueres (ESP) \\
\hline Woman, 55 & Spain & $>10$ & Employee & Secondary School & Roses (ESP) \\
\hline Man, 35 & Moroceo & $5-10$ & Employee & $\begin{array}{l}\text { Town hall welcoming and immi- } \\
\text { gration service }\end{array}$ & Figueres (ESP) \\
\hline Man, 70 & France & $>10$ & Volunteer & Les Restos du Coeur & Perpignan (FR) \\
\hline Woman, 70 & France & $>10$ & Volunteer & La Cimade & Perpignan (FR) \\
\hline Woman, 35 & Romania & $>10$ & Volunteer & Secours Populaire & Perpignan (FR) \\
\hline Woman, 45 & France & $<5$ & Employee & Enfance Catalane & Perpignan (FR) \\
\hline Woman, 45 & Venezuela & $<5$ & Volunteer & Secours Catholique & Perpignan (FR) \\
\hline Woman, 55 & France & $>10$ & Employee & ACAL & Perpignan (FR) \\
\hline Man, 45 & France & $5-10$ & Employee & Red Cross & Perpignan (FR) \\
\hline Woman, 30 & France & $>5$ & Employee & Red Cross & Perpignan (FR) \\
\hline Woman, 30 & France & $>5$ & Employee & Red Cross & Perpignan (FR) \\
\hline Woman, 70 & France & $<10$ & Activist & ASTI & Perpignan (FR) \\
\hline Man, 70 & France & $5-10$ & Activist & ASTI & Perpignan (FR) \\
\hline Man, 30 & France & $5-10$ & Activist & Collectif sans papiers 66 & Perpignan (FR) \\
\hline
\end{tabular}

One of the objectives of migrants to France is to obtain the right of asylum. In the 1980s, in the midst of an economic crisis, the French government changed its policy in terms of reception. If initially, when the Socialist Party came to power in 1981, the French state had granted broader rights to foreigners - access to the labour market and a residence permit for ten years - as of 1983 the situation would become more complicated. It was precisely in these two aspects where changes would occur. Starting in 1991, access to the labour market for foreigners was regulated - for each foreigner the prefecture had to assess whether French workers were also competing for the work they were seeking, depending on the employment sector and geographical area - and the profile of demandeur d'asile (asylum seeker) became stigmatised. From that moment on, the right of asylum was a recurring subject of reform and political debate in the state. In 2015, this aspect was again reformed to fit European law, and, since then, French and European judges have issued conflicting decisions.

The French Parliament is currently debating a new bill (Asile et immigration) on the right of asylum. This law provides for administrative and legal tightening of asylum conditions (reduction of resources for migrants and increased durations of administrative detention), with repercussions for the migrants themselves, as well 
as for the people who support them and work in welcoming (Geisser 2018).

If, as we have seen, Northern Catalonia has traditionally been a place of administrative "retention" for migrants - and continues to be so with two Centres d'Accueil de Demandeurs d'Asile (CADAs; reception centres for asylum seekers and refugees) - another characteristic of the territory is the support of humanitarian organisations with a more militant left-wing attitude toward these individuals. At the end of the twentieth century, migrant support groups were formed, including the Collectif sans papiers de Perpignan. One of the Collectif's first battles was that of the chibanis, ${ }^{5}$ old workers from the Maghreb who - for economic and administrative reasons - cannot live out their old age with their families in their country of origin.

At present, the Collectif sans papiers de Perpignan is exceptional in the French state. This group comprises different political and trade union entities (ranging from the Greens to anarcho-syndicalism) and is structured around two migrant aid associations: La Cimade and Association de Solidarité avec Tous les Immigrés (ASTI). Its aim is to politicise the issue of the reception of migrants and fight for their regularisation.

Another entity that works in Perpignan together with the Collectif is Bouge-Toit. Denouncing the negligence of institutions in accommodating vulnerable migrants, its task is to seize empty public buildings to turn them into dwellings occupied by people who have been denied the right to asylum. Depending on the political moment, this strategy has had different repercussions. While the first occupation of a building ended with the regularisation of all its occupants, nowadays the main interest of Bouge-Toit is to obtain resettlement for families from the prefecture who are seeking social housing.

In comparison, in other French cities, the Collectifs sans papiers are groups where migrants self-organise to bring their claims. In Perpignan, members of different organisations - both migrants and natives - have created the Collectif. When it comes to understanding this phenomenon, many people who participate in this movement for welcoming immigrants refer to the Retreat: for some, it represents a fissure that allowed them to enter the territory; for others, it is the origin of a tradition of welcoming on the part of the city's inhabitants. Many long-time activists in the Collectif sans papiers as well as other humanitarian organisations have personal ties with the Retreat, as they are children of Spanish refugees. The strength of this organisation's support of the cause of migrants enables them to put pressure on public institutions - for example, the prefecture of
Perpignan - and to publicise the situation of migrants in Northern Catalonia.

\section{Immigration and "Reception Law" in the Principality of Catalonia}

In Catalonia, immigration has historically been a consubstantial element in understanding its demographic dynamics. Throughout the twentieth century, in particular, the Principality of Catalonia experienced three major migratory flows: two of an internal nature, between 1915 and 1930 and between 1940 and 1975, coming from the rest of Spain, and the most recent with international immigration. With regard to internal immigration, the beginning of immigration during the Franco regime is particularly significant, as more than two million immigrants were received (Marín 2009). This phenomenon gave rise to the expression "Catalonia, land of welcome," which is still used today in discourse on foreign immigration (Domingo 2014).

Foreign immigration to the Catalan regions located to the south of the border began in the mid-1980s, especially with the arrival of populations from the Maghreb and Sub-Saharan Africa. The population census data ${ }^{6}$ show how the counties of Girona (the closest city to the border) had, at the beginning of 2000, a foreign population of 6.2 percent, a figure that rose to 21.4 percent in 2012 . This data, however, do not reveal the very different profiles of the foreigners whom these counties have welcomed: from French and English pensioners with high purchasing power who have been attracted by good living conditions, to people from rural Gambia and Morocco, fleeing poverty in search of new opportunities in Europe. Initially, welcoming actions and support for foreign newcomers fell primarily on social organisations, especially trade unions (Comissions Obreres and Unió General de Treballadors), social assistance organisations (Caritas and Red Cross) and social movements specialising in welcoming ethnic minorities (Grup de Recerca i Actuació sobre Minories Culturals, Fundació Sergi, etc.). The role of some public sector professionals, especially pediatricians and social workers, is also noteworthy, although their actions have been more individual decisions than an institutional resolution. However, as immigration has become a structural reality in the whole of the Principality, public institutions - with the leadership of the regional government (Generalitat de Catalunya) and involvement of local authorities - have developed local reception and integration policies, and promoted specialised units of professionals to head services and projects designed to foster integration and accommodation of immigration. All of this has been coordinated, to a certain degree, 
with social entities, which continue performing their traditional functions.

Since 1993, the government of Catalonia has developed six plans to promote the integration of immigrants. Despite this political initiative, these plans have been hindered by the lack of competencies in critical areas for integration, especially in matters of immigration, which are the purview of Spain. The Catalan case is a clear example of multilevel governance of immigration (Geddes and Scholten 2015), which has led to major conflicts of jurisdiction between the Spanish and Catalan governments. ${ }^{7}$ In general terms, Spain has exclusive powers in matters of immigration and nationality, while the autonomous communities and local authorities have competencies in basic aspects of integration, such as health, education and social services. However, analysis of political texts from these years highlights the definition of Catalan society as a welcoming society that has historically received various immigration flows that have given it a diverse and plural character, and in which immigration has made a decisive contribution to social and demographic growth. Welcoming, therefore, is part of the political and social narrative on immigration in the Principality.

However, the welcoming of immigrants, understood as a specific strategic line of integration policies, was not a priority until the approval of the Statute of Autonomy of Catalonia in 2006 (an Organic Law establishing the autonomous government), in which reception and integration are recognised as the competence of the government of Catalonia. In accordance with this competence, in 2010, the "Law 10/2010, on the reception of immigrants and returnees to Catalonia" was passed, being the first law in Spain to address this matter. Inspired by the experience of other regions, such as Quebec and Flanders (Franco-Guillén 2017), as well as recommendations from the European Commission (European Commission 2007), the law seeks to promote knowledge among the newly arrived population about Catalan society and its norms and institutions, as well as public services and basic linguistic skills.

According to this law, welcoming is understood as the first stage in the integration process, and its services must be coordinated and complemented with others equally necessary for integration, especially those related to basic social rights, including education, health, housing and employment. To achieve this, reception services are structured as a first welcoming service and specialised programs. The first welcoming service is considered a right of foreign immigrants, asylum seekers, stateless persons and refugees (Art. 7.1), as well as a duty for local authorities. This service consists of providing information about the host society, as well as 120 hours of training distributed in 90 hours of basic language skills, 15 hours of work-related knowledge, and 15 hours of knowledge about Catalan society and its legal framework.

The town councils have been designated as the reference points for accessing welcoming services, especially after registration of residency. ${ }^{8}$ Yet what is probably most important about the reception services in Catalonia is the possibility of using their certifications in regularisation processes, even though this is a competence of the Spanish state. Thus, in certain cases, these certificates are positively valued elements, in spite of not being decisive.

City and town councils are of crucial importance in this process, which some authors have defined as the local turn on multilevel governance (Zapata, Caponio and Scholten 2017), as well as social movements and NGOs (Martín Díaz and Bermúdez Torres 2017). This is not only because they are the administration closest to citizens, where immigrants settle and are more readily identified, but also because they are at the local level, where the effects of the arrival of newcomers are most evident. The application, therefore, of the law on reception was an important opportunity for municipalities to develop reception and integration policies, as well as to create technical structures - employing qualified professionals with the desire to work with the different institutional actors - but also to foster collaboration with social entities. To make the latter possible, the law was accompanied by resources and funding, with collaboration agreements between the government of the Generalitat of Catalonia and the city and town councils, or the consells comarcals (supra-municipal entities), as well as calls for subsidies for social and third-sector entities. The leadership of the public sector, therefore, has not meant the disappearance of the social entities that had traditionally taken responsibility for welcoming. The law itself established in its principles of action the need to work jointly and in coordination with all stakeholders in order to provide comprehensive and versatile solutions.

\section{Perspectives on the Welcoming of Migrants on Both Sides of the Border}

The internal structure at the organisational and labour level of organisations that carry out tasks for welcoming immigrants is very unequal, both between territories and between organisations. Organisations that develop and implement government programs and receive state funding tend to have more hired staff, while others rely to a greater extent on volunteers. Organisations located in Perpignan that perform functions on behalf of the French government receive considerable amounts of money in comparison to those performing different 
tasks outside of official channels. The largest of these is Association Catalane d'Actions et de Liaisons (ACAL), which has 13 establishments between lodging centres for asylum seekers and other services. Its staff of 120 employees assists more than 2,000 people per year, with a contribution from the state of about six million euros. At the other extreme we find organisations such as ASTI or La Cimade, which carry out welcoming and legal support tasks for immigrants with very low budgets. To the south of the border we do not find organisations equivalent to ACAL in terms of the volume of funding and number of employees. Besides the municipal offices with one or two social workers that we find in municipalities, non-governmental organisations also work in small premises and have very low budgets.

Staff personnel usually have training in the field of social work, while among volunteers training is more diverse and we find professionals from different fields who devote their time to volunteering after retirement. For example, at Restos du Coeur, an organisation dedicated to welfare functions in Perpignan (distribution of food and clothing, French-language classes, etc.), the individuals responsible for its operation are a retired teacher and doctor; while in Caritas, an organisation that performs similar functions in Figueres, the person in charge is a Christian Democrat politician, former deputy and former mayor, also retired. One difference between the two sides of the border is that in the south we find more technical personnel of migrant origin, while in the north the presence of migrant personnel is greater among volunteers.

Volunteers constitute a major part of the human resources of the organisations that work for the reception of people of migrant origin. This is true in both large and small organisations, as well as in those that have a greater volume of contracted personnel. The profile of volunteers corresponds mainly to native women over 60 years of age. We also find some volunteers from migrant backgrounds. This is a very diverse collective, essential for the operation of welcoming, but which nevertheless presents some formative shortcomings that hinder them from performing their functions in a more professional way. For example, a 45-year-old psychologist who volunteers in a social organisation of a religious nature expressed her criticism of other volunteers who were displaying paternalistic attitudes:

They are older people; they want to help but their comments are terrible. Sometimes you have people waiting and you see two volunteers speaking among themselves in French, but people understand what they're saying, and they make derogatory comments like "Look at her, this one comes here to ask for help ..."; they're not doing a professional job.
In the Principality of Catalonia, the arrival of foreign population slowed in 2009 due to the economic crisis. However, welcoming services still have to attend, for example, to people who find themselves in unexpected or irregular situations, usually because residence permits are linked to employment contracts, and with the economic crisis suffered by Spain in the last decade, unemployment rates have been very steep, reaching 27 percent in 2015. The situation in Northern Catalonia, also marked by the general context of France, is different. Many foreign people continue to arrive today, mainly asylum seekers from a number of different countries, especially in Eastern Europe, Asia and the Middle East.

In both regions, immigrants discover the existence of welcoming services mainly through informal channels and social networks. The woman in charge of one of the services that offers temporary accommodation to asylum seekers in Perpignan explained to us that when a family has to leave, they already have another waiting at the door before the vacancy is made public through official channels: "Sometimes there are families at the door early in the morning; the information reaches them through Facebook." Also, in both regions there is a flow of migrants between different services, guided by the employees or volunteers themselves, which goes in the direction of NGOs to the administration and vice versa. There are even cases in which workers in administration services end up directing, sotto voce, migrants to social protest movements such as the PAH (Platform for People Affected by Mortgages) ${ }^{9}$ in the Principality, which, among other things, gives advice on how to occupy apartments repossessed by banks. An important difference between the two sides of the border is the much more decisive presence of the administration of the state in France, which in large part directs the reception of individuals going through the process of demanding asylum, while in Spain the state administration is present only in terms of the regulation of foreigners, not their reception, which, in accordance with Law 10/2010 mentioned above, is the responsibility of the regional government, with the collaboration of local authorities.

Unfortunately, given the difficulty of knowing how many undocumented people reach these countries, we do not have the possibility of offering precise figures, but through speaking with agents who work in welcoming services we can deduce that the arrival of new immigrants in the Principality is at this moment much lower than that observed in Northern Catalonia.

Weak financing limits the action of the organisations that work to assist the migrant population on both sides of the border. However, the main limitation of welcoming actions on the southern side of the border is, according to 
people from the organisations, the lack of housing to accommodate immigrants, while in the north the action of the organisations is most limited by the lack of regularisation of immigrants by the state. That is, in all the interviews conducted to the south of the border, the absence of mechanisms to provide accommodation for arriving refugees or immigrants who cannot afford to pay rent appears as a recurrent theme, whereas in all the interviews from the north side of the border, the recurring theme is the great weight that humanitarian organisations must carry in order to handle asylum claims, bring appeals to the court of justice to fight expulsion proceedings or attend to the urgent needs of people in irregular situations and therefore deprived of social coverage. This does not mean that to the south there are no legal problems nor to the north housing problems, but this is where the people who work in the organisations place the emphasis.

As the informants explain in the interviews, newly arrived immigrants in the welcoming country are usually unaware of the functioning of the public administration and especially the administration of justice. Because of this, welcoming in itself often consists of first providing advice on these topics. The tightening of administrative procedures for foreigners, however, has meant that on both the south and north of the Catalan border, legal advice is one of the main tasks undertaken by organisations working in welcoming. For example, in the Principality, Caritas has ten employees (six lawyers and four technicians) who travel to different towns on the south side of the border providing legal consultation services. In Northern Catalonia, difficulties in obtaining asylum status, and the large number of rejected applications, have resulted in many organisations being overwhelmed at this time with a task they perform in a very serious and professional way, despite the fact that volunteers often do this work.

Assistance services are also an important part of the actions carried out by organisations working in welcoming. These consist primarily of the distribution of food, clothing and monetary aid south of the border, and the same services plus emergency accommodation to the north. The need for assistance was one reason for the founding of many of these organisations, some of them, such as Caritas and Secours Catholique - both centenarian - with the aim of providing the most disadvantaged citizens with basic social rights not provided by the state at the time these entities were created and that continue, in the case of immigrants, to be neglected by the state administration. The danger of being trapped in the dynamics of their state is leading some of these entities to rethink their role in relation to the administration. As expressed by an activist at the ASTI in Perpignan during an interview, there is such a serious humanitarian crisis in France that solidarity networks have been launched everywhere, but in the end this poses a problem because you cannot do this non-stop. We need to put it at a more general political level. It cannot be that we get to the point where the associations do the work of the state.

Training is also one of the pillars of welcoming and is one of the activities that involves the greatest number of people, both volunteers of these organisations and immigrants. Training also mobilises many economic, space and management resources of organisations. In Northern Catalonia, learning French is arguably the centre of the welcoming action, while in the Principality, learning the language is just another aspect of training. On both sides of the border, training is important for labour insertion and for the processing of permits for migrants to be able to reside stably in the country.

On both sides of the border, welcoming is understood by the agents themselves, as stated in our interviews, as "being attentive to the needs of the other" and "knowing how to listen to people who come to the organisations, helping them, first of all, to feel calm, and accompany them in the process of stabilising their situation in the country receiving them." However, the general context of the country in terms of migratory flows and state policies weighs heavily on the view of welcoming. While in the Principality the arrival of new migrant population decreased a decade ago, large numbers of asylum seekers continue to arrive in Northern Catalonia and soon become deboutés - that is, dismissed from the public system. In view of this, we find a critical attitude from people who participate in some of the more politically oriented organisations and believe that the Spanish and French states are deploying a policy of non-reception that is leading to a situation of humanitarian crisis. Some volunteers consider that subsidies to organisations to carry out welfare tasks run the risk of becoming a way for the state to control them.

Welcoming also involves a process of integration, but the concept of integration is controversial. Its interpretation swings between two extremes: assimilation and inclusion. Here, we can also make a distinction more marked north than south of the border due to the greater weight of the state administration in the north compared to greater local autonomy in the south between organisations working in welcoming programs funded by the state and those working from a more critical standpoint or even openly opposed to the migration policies of Europe.

In Northern Catalonia, as we have seen above, some organisations manage a substantial budget of public 
funds to cover the housing needs of asylum-seeking immigrants at the behest of the government. One of the individuals working in one of these organisations affirmed that people who are staying in their establishments "need integration," and when asked to explain what this means, they replied, "Learning to use a microwave when you come from Sudan may seem obvious, but ...." This is an interpretation of integration in an assimilationist mode, based on an ethnic prejudice according to which the Sudanese are people who are ignorant regarding the operation of household appliances.

The view of welcoming is quite different, though, when we speak to volunteers from these organisations who have a migrant background themselves. For example, a volunteer, of Romanian origin, working in an organisation in Northern Catalonia coordinating French courses for foreigners explained that she always advises people who attend French-language courses to preserve the culture and language from their countries and transmit this to their children: "If you talk about your country, they will be of the French culture and the culture of your country as well. They will have two; cultures add up." Similarly, another volunteer, of Moroccan origin, in an organisation in the Principality expressed their disagreement with the concept of integration as follows: "When you integrate you form part of a mass, assimilate an environment, and cease to be you." We see here that some visions of welcoming come into play in these organisations that are more oriented to inclusion than to assimilation.

Regardless of the views of individual volunteers and staff of welcoming, the orientation of public welcome policies is driven by government agencies and is therefore different on the two sides of the border. The government largely determines the discourses and practices on the welcoming of migrants at the level of daily practice, by the organisations that work in welcoming and especially by the people who are carrying out the organisations' activities. However, as we have seen, there is a critical reflection on this practice by the agents themselves both north and south of the Catalan border.

\section{Conclusions}

In this article we have presented the reception and welcoming of immigrants from the point of view of the organisations that carry out these actions, and more specifically the people who work or volunteer in them or collaborate as activists. We have situated the study in two border regions of two member states of the European Union that, together, make up a Eurodistrict - a cross-border cooperation area with a shared national past. However, despite the historical-cultural continuity and the geographical proximity of the main cities, Figueres and Perpignan, the different legal and administrative situations in the two states have a decisive influence on the type and functions of their welcome systems.

We note that the greater presence of the French state in organisations in Northern Catalonia limits their capacity for initiative; hence, they focus mainly on providing legal support and teaching of the French language. On the other side of the border, the decentralised administration of Spain has enabled Catalonia, a region with a strong desire to self-determine its own legislation, such as the reception of the migrant population, to develop a law that opens the door to inclusion policies. However, in light of the tendency to identify the French model as assimilationist, the historical experience of a territory such as Northern Catalonia is an important factor in understanding welcoming by the local population. An informant from Perpignan told us the following anecdote: A middle-class Algerian couple had immigrated to Marseille for a matter related to the health of their young daughter. Unfortunately, in Marseille they were badly advised and her situation worsened. Through Facebook, they learned that there was a very active movement in Perpignan and they decided to go there, where one of the organisations fighting for the defence of the rights of immigrants welcomed them and found them a place to live. Undoubtedly, the memory of the Retreat has had a certain influence in making this region a land of welcome, a discourse that we have also seen in Catalonia, but on the institutional level.

Our research leads us to conclude that there is an activist movement in Northern Catalonia that is strongly committed to welcoming in the face of a political and legislative context that displays the opposite tendency. In contrast, in Catalonia, the organisations dedicated to welcoming actions have a more collaborative approach to government institutions and are not as combative as in the north. This is due to the existence of a public welcoming network that offers services and resources aimed at facilitating knowledge of the environment and of the public and private resources available to migrants. This public network, although it favours more coordinated action between public services and non-governmental organisations, is not capable of responding to all the needs of newcomers - especially irregular migrants - or those needs that derive from insufficient development of social welfare policies, which are often the responsibility of the regional and local government (Spencer and Delvino 2019).

According to our analysis, even though both cases show different responses toward welcoming migrants, they also demonstrate the effects of multilevel 
governance of immigration on various domains, especially the consequences of different national models of immigration and the difficulties of the regional and local governments to design and implement policies adapted to their reality, and not only in consonance with the national perspective. According to Gebhardt (2014), our research demonstrates the necessity not only to improve and reconcile national and local perspectives on integration policies, but also to improve the coordination and cooperation between different levels of government.

From our work, we draw some conclusions that may be relevant to understanding the current level of European integration in connection with the migratory phenomenon. First, we observe certain differences in reception to the north and south of the Catalan border that can teach us something about the conditions that give rise to a relatively welcoming society. To begin with, more money does not necessarily imply more welcome. We have been able to observe that organisations located on the French side of the border dispose of more resources from public budgets than those on the Spanish side, which, for example, do not have mechanisms in place for emergency housing for newly arrived immigrants. This, however, does not mean that reception is more developed to the north than to the south. That is, reception is not something that can be assessed only in terms of public funding devoted to it. Rather, we observe that a decentralised administration closer to the territory in question responds better to the needs of humanitarian organisations working in welcoming than a more centralised state administration like that of the French, despite the latter's greater financial resources. In this sense, Catalonia has been able to develop a reception law of its own that, despite insufficient funding, is valued positively by people who work in the field of reception, either as volunteers or as employees of humanitarian organisations.

Another important element in analysing the conditions that make a society more inclined to be welcoming is undoubtedly the experience of recent history. The fact of being a region of southern Europe, where migrations have been an integral part of the demographic dynamics at least since the beginning of the twentieth century, seem to have predisposed certain local actors - as is evident from our interviews, especially in Northern Catalonia - toward a proactive attitude in welcoming immigrants for humanitarian reasons. Yet at the same time, we must not forget that the xenophobic extreme right has obtained increasing electoral support here, as in all of Europe. The situation is therefore quite complex and contradictory.

Finally, it should be noted that, at present, a newcomer's experience will differ depending on whether they arrive in Figueres or Perpignan. Despite geographical proximity, despite being in a Catalan country in both the north and south and despite having reached the same Eurodistrict, it must be emphasised that state political borders exert the primary role in the daily lives of immigrants, even within a common policy space, as is the EU. Thus, all those facilities promoted by Eurodistricts for the exchange and proximity of inhabitants of cross-border areas within the EU, do not apply to the migrant population or their reception.

To conclude, and regarding what we have just said, the term "welcoming" is at least as polysemic as "integration." When we speak of welcoming, we speak of different visions that coincide with the same action (or actions), which are more or less agreed upon. However, depending on the position of the agents working to facilitate welcoming on behalf of the state, (from more akin to more critical), the vision of reception may vary fundamentally. Therefore, it is difficult to expect coordinated action between all stakeholders involved, given that in reality, they understand welcoming differently, even when not in mutually contradictory ways (following an administrative procedure exactly versus seeking alternatives to skirt legal channels). Rather than speaking about welcoming, we should speak about welcomings, in the plural. We can say that welcoming is a practice that has many paths, which may open different doors of integration into society.

Eliseu Carbonell, Lecturer, Department of Pedagogy, University of Girona (Spain). Email: eliseu. carbonell@udg.edu.

Xavier Casademont, Lecturer, Department of

Pedagogy, University of Girona (Spain). Email: xavier. casademont@udg.edu.

Josep-Miquel Palaudarias, Lecturer, Department of Pedagogy, University of Girona (Spain). Email: josep. palaudarias@udg.edu.

Gautier Sabrià, Lecturer, Institut Regional del Treball Social, University of Perpinyà Via Domitia (France).

Email: gau.sabria@gmail.com.

\section{Notes}

1 See Eurodistrict of the Catalan Cross-Border Area, "What Is the Catalan Crossborder Area?," n.d. http://www. eurodistricte.cat/en/what-catalan-crossborder-area.

2 For example, employment opportunities, fostering social capital, affordable and suitable housing, educational opportunities, accessible health care, safety and favourable media coverage, among others (see Esses et al. 2010).

3 On the concept of integration, see Oliver (2016). 
4 See "P.-O.: l'ancien flic dénonce la chasse 'aux faux clandestins,"” LIIndépendant, 12 April 2018. https://www. lindependant.fr/2018/04/12/p-o-lancien-flic-denonce-lachasse-aux-faux-clandestins,3915440.php.

5 In Western Arabic, chibani means "white hair" or elder.

6 For more information, see data from the Spanish National Statistical Institute or the Catalan Statistical Institute.

7 Thus, for example, in 2010 the Spanish government filed an appeal of unconstitutionality against article 9 of the Catalan law for the reception of immigrants.

8 The register of inhabitants is an administrative register that identifies the individuals that live in a given municipality in the Spanish state. Legislation allows registered foreigners, even those who are in an irregular situation, to access a series of basic services; however, to be able to access them, they must be registered. Additionally, it is usually a document that certifies the date of arrival in the country. For all these reasons, foreigners have incentives to register, even if they are not in a regularised administrative situation.

9 The Platform for People Affected by Mortgages is a social movement in favour of the right to housing that came into being in 2009 at the height of the eviction crisis in Spain. Many of the people affected by this problem were foreigners, and PAH has become the most important actor in providing support and advice to the people affected.

\section{References}

Ager, Alastair, and Alison Strang. 2008. "Understanding Integration: A Conceptual Framework." Journal of Refugee Studies 21 (2) : 166-191. https://doi.org/10.1093/ jrs/fen016

Alland, Alexander, and Sonia Alland. 2006. Catalunya, One Nation, Two States: An Ethnographic Study of Nonviolent Resistance to Assimilation. New York: Palgrave Macmillan.

Augé, Jean-René. 2018. Les faux chiffres de l'immigration clandestine dans les Pyrénées-Orientales. Perpignan: Roussillon Editions.

Bacon, David. 2008. Illegal People: How Globalization Creates Migration and Criminalizes Immigrants. Boston: Beacon Press.

Back, Less, and Sinha Shamser. 2012. "Migration and the Terms of Inclusion.” In Young Migrants: Exclusion and Belonging in Europe, edited by Katrine Fangen, Thomas Johansson, and Nils Hammarén, 54-86. London: Palgrave Macmillan.

Bernard, Philippe. 2002. Immigration: Le défi mondial. Gallimard: París.

Bouba, Philippe. 2009. L'Arrivée des Pieds-Noirs en Roussillon en 1962. Perpignnan: Éditions Trabucaire.

Brown, Wendy. 2010. Walled States, Waning Sovereignty. New York: Zone.

Burr, Kathleen. 2011. "Local Immigration Partnerships: Building Welcoming and Inclusive Communities through Multi-Level Governance." Horizons Policy Research Initiative, 1-9. Ottawa: Citizenship and Immigration Canada. Retrieved from http://p2pcanada.ca/wp-content/ uploads/2011/10/Local-Immigration-Partnerships-BuildingWelcoming-and-Inclusive-Communities.pdf
Corbet, Alice, and Michalon Bénédicte. 2017. "Collaborer avec des organismes non gouvernementaux pour enquêter sur les camps de migrants et de déplacés. Le savoir comme enjeu professionnel". Migrations Société 167 (1): 53-62.

Crépon, Sylvain, Alexandre Dézé, and Nonna Mayer. 2015. Les faux-semblants du Front national: Sociologie d'un parti politique. Paris: Presses de Sciences Po.

Derwing, Tracey M., and Harvey Krahn. 2008. "Attracting and Retaining Immigrants Outside the Metropolis: Is the Pie Too Small for Everyone to Have a Piece? The Case of Edmonton, Alberta." Journal of International Migration and Integration 9 (2): 185-202. https://doi.org/10.1007/ s12134-008-0050-3

D'Appollonia, Ariane. 2007. "Xenofobia y extremas derechas en Europa" ["Xenophobia and Far Right in Europe"]. In La extrema derecha en Europa desde 1945 a nuestros días [The Far Right in Europe from 1945 to Today], edited by M.A. Simón, 187-203. Madrid: Tecnos.

Domingo, Andreu. 2014. Catalunya al mirall de la immigració: Demografia i identitat nacional [Catalonia in the Mirror of Immigration: Demographics and National Identity]. Barcelona: L'Avenç.

Dukic, Suzana. 2009. "Deux siècles d'immigration LanguedocRoussillon”. Hommes et Migrations 1278: 76-87. https:// doi.org/10.4000/hommesmigrations.230

Düvell, Franck. 2011. "Paths into Irregularity: The Legal and Political Construction of Irregular Migration.” European Journal of Migration and Law 13 (3): 275-295. https://doi. org/10.1163/157181611X587856

Enríquez, Carmen. 2009. "Spain, the Cheap Model: Irregularity and Regularisation as Immigration Management Policies." European Journal of Migration and Law 11 (2) : 139-157. https://doi. org/10.1163/157181609X440004

Esses, Victoria, Leah K. Hamilton, Caroline BennettAbuAyyash, and Meyer Burstein. 2010. "Characteristics of a Welcoming Community.” Welcoming Communities Initiative. Ottawa: Citizenship and Immigration Canada. Retrieved from http://p2pcanada.ca/wp-content/ uploads/2011/09/Characteristics-of-a-WelcomingCommunity-11.pdf (accessed 2 September 2019).

European Comission. (2007). Handbook on Integration for Policy-makers and Practitioners. 2nd edition. Brussels.

Franco-Guillén, Núria. 2017. Immigració $i$ independència. Els casos del Quebec, Escòcia i Catalunya [Immigration and Independence. The Cases of Quebec, Scotland and Catalonia]. Barcelona: Fundació Irla.

Frozzini, Jorge, and Danielle Gratton. 2015. "Travail migrant temporaire et précarisation”. Vie Économique 7 (1): 1-10. Retrieved from http:/www.eve.coop/?a=240

Frozzini, Jorge, and Alexandra Law. 2017. "Pour une compréhension de l'hétérogénéité des visions du monde lors de l'implication dans la défense et l'aide aux (im) migrants". Anthropologie et Sociétés 41 (3): 131-154. https://doi.org/10.7202/1043045ar

Garcés-Mascareñas, Blanca, and Rinnux Penninx. 2016. “The Concept of Integration as an Analytical Tool and as a Policy Concept." In Integration Processes and Policies in European Contexts, Levels and Actors, edited by Blanca Garcés-Mascareñas and Rinus Pennix, 11-29. Amsterdam: IMISCOE. 
Gebhardt, Dirk. 2014. Building Inclusive Cities: Challenges in the Multilevel Governance of Immigrant Integration in Europe. Washington, DC: Migration Policy Institute.

Geddes, Andrew, and Peter Scholten. 2015. "Policy Analysis and Europeanization: An Analysis of EU Migrant Integration Policymaking." Journal of Comparative Policy Analysis: Research and Practice 17 (1): 41-59. https://doi. org/10.1080/13876988.2013.849849

Gehring, Jacqueline. 2013. "Free Movement for Some: The Treatment of the Roma after the European Union's Eastern Expansion." European Journal of Migration and Law 15 (1): 7-28. https://doi.org/10.1163/1571816612342021

Geisser, Vincent. 2018. "Projet de loi sur l'asile et l'immigration: Indignation morale versus cynisme gouvernemental?" Migrations Société 171 (1): 3-11. https://doi.org/10.3917/migra.171.0003

George, Glinis, and Erwin Dimitri Selimos. 2018. "Using Narrative Research to Explore the Welcoming of Newcomer Immigrants: A Methodological Reflection on a Community-Based Research Project." Forum: Qualitative Social Research 19 (2): Art. 9. http://dx.doi.org/10.17169/ fqs-19.2.2907

George, Glynis, Erwin Dimitri Selimos, and Jane Ku. 2017. "Welcoming Initiatives and Immigrant Attachment: The Case of Windsor." Journal of International Migration and Integration 18 (1): 29-45. https://doi.org/10.1007/ s12134-015-0463-8

Heckmann, Friedrich. 2006. Integration and Integration Policies. Bamberg: European Forum for Migration Studies.

Huang, Xi and, Cathy Yang Liu. 2018. "Welcoming Cities: Immigration Policy at the Local Government Level." Urban Affairs Review 54 (1): 3-32. https://doi. org/10.1177/1078087416678999

Joppke, Christian. 2017. Is Multiculturalism Dead? Crisis and Persistence in the Constitutional State. Cambridge: Policy Press.

Julien-Laferrière, François. 2016. "1983-1993: Dix ans de revirements. Du réfugié bienvenu au demandeur d'asile indésirable”. Migrations Société 165 (3): 75-90. https://doi. org/10.3917/migra.165.0075

Kabunda, Mbuyi. 2012. "Migraciones internas y externas africanas: isuerte o maldición?" ["African Internal and External Migrations: Luck or Curse?"]. In África en movimiento [Africa in Movement], edited by Myubi Kabunda, 11-38. Madrid: Catarata.

Khosravi, Shahram. 2007. "The 'Illegal' Traveller: An Autoethnography of Borders.” Social Anthropology 15 (3): 321-334. https://doi.org/10.1111/j.0964-0282.2007.00019.x

Knott, Alexandra. 2018. "Guests on the Aegean: Interactions between Migrants and Volunteers at Europe's Southern Border.” Mobilities 13 (3): 349-366. https://doi.org/10.1080/ 17450101.2017.1368896

Lauth Bacas, Jutta. 2013. "Managing Proximity and Asymmetry in Border Encounters: The Reception of Undocumented Migrants on a Greek Border Island." In Border Encounters: Asymmetry and Proximity at Europe's Frontiers, edited by Jutta Lauth Bacas and William Kavanath, 255-280. New York: Berghahn Books.

Lazaridis, Gabriella, and Mariangela Veikou. 2017. "The Rise of the Far Right in Greece and Opposition to 'Othering,'
Hatespeech, and Crime by Civil and Civic Organizations." Journal of Civil Society 13 (1): 1-17. https://doi.org/10.108 0/17448689.2016.1251032

Lebourg, Nicolas. 2011. "Le camp de Rivesaltes: Bilan et perspectives d'un lieu d'ostracisme (1939-2007)". Annales du Midi: Revue Archéologique, Historique et Philologique de la France Méridionale 123 (275): 409-424. https://doi. org/10.3406/anami.2011.7374

Marín, Martí. 2009. "Fluxos, stoks, periodicitat i origen" ["Flows, Stoks, Periodicity and Origin"]. In Memòries del viatge (1940-19\%5) [Memories of Travel (1940-1975)], edited by M. Marín, 13-32. Sant Adrià del Besòs: MHICAjuntament de Sant Adrià del Besòs.

Martín Díaz, Emma, and Anastasia Bermúdez Torres. 2017. "The Multilevel Governance of Refuge: Bringing Together Institutional and Civil Society Responses in Europe and Spain.” In Maintaining Refuge: Anthropological Reflections in Uncertain Times, edited by David Haines, Jayne Howell, and Fethi Keles, 87-95. Arlington: Committee on Refugees and Immigrants.

Moumen, Abderahmen. 2010. "De l'Algérie à la France. Les conditions de départ et d'accueil des rapatriés, piedsnoirs et harkis en 1962". Matériaux pour l'Histoire de Notre Temps 99 (3): 60-68. https://doi.org/10.3917/mate. 099.0060

Naïr, Sami. 2007. Limmigration est une chance. Entre la peur et la raison. Paris: Seuil.

National Working Group on Small Centre Strategies. 2007. Attracting and Retaining Immigrants: A Tool Box of Ideas for Smaller Centres. Victoria: Inter-Cultural Association of Greater Victoria.

Oliver, Caroline. 2016. Review of the Research Literature on Integration and Resettlement in Europe and the Impact of Policy Interventions. Oxford: COMPAS.

Pécoud, Antoine and Paul de Guchteneire. 2011. "International Migration, Border Controls and Human Rights: Assessing the Relevance of a Right to Mobility." Journal of Borderlands Studies 21 (1): 69-86. https://doi .org/10.1080/08865655.2006.9695652

Regnault, Élisabeth, Michele Racine, and Jacqueline Breugnot, eds. 2018. "Laccueil des migrants au Canada et en Europe". Revue Française d'Éducation Comparée 16.

Samers, Michael. 2004. "An Emerging Geopolitics of 'Illegal' Immigration in the European Union." European Journal of Migration and Law 6 (1): 27-45. https://doi. org/10.1163/1571816041518750

Spencer, Sarah. 2011. The Migration Debate. Bristol: The Policy Press.

Spencer, Sarah, and Katharine Charsley. 2016.

"Conceptualising Integration: A Framework for Empirical Research, Taking Marriage Migration as a Case Study.” Comparative Migration Studies 4 (1): 1-18. https://doi. org/10.1186/s40878-016-0035-x

Spencer, Sarah, and Nicola Delvino. 2019. "Municipal Activism on Irregular Migrants: The Framing of Inclusive Approaches at the Local Level." Journal of Immigrant and Refugee Studies 17 (1): 27-43. https://doi.org/10.1080 /15562948.2018.1519867

Spijkerboer, Thomas. 2007. "The Human Costs of Border Control." European Journal of Migration and Law 9 (1): 127-139. https://doi.org/10.1163/138836407X179337 
Stolcke, Verena. 1995. "Talking Culture: New Boundaries, New Rhetorics of Exclusion in Europe." Current Anthropology 36 (1): 1-24. https://doi.org/10.1086/204339

Thorleifsson, Cathrine. 2017. "Disposable Strangers: Farright Securitisation of Forced Migration in Hungary." Social Anthropology 25 (3): 318-334. https://doi. org/10.1111/1469-8676.12420

Tuban, Grégory. 2018. Camps d'étrangers. Le contrôle des réfugiés venus d'Espagne (1939-1944). Paris: Nouveau Monde Éditions.

Veron, Daniel. 2013. "Cartographie de la frontière et topographie clandestine". Hommes and Migrations 1304 (4): 19-25. https://doi.org/10.4000/hommesmigrations. 2630

Vertovec, Steven, and Sussan Wessendorf. 2010. The Multiculturalism Backlash: European Discourses, Policies and Practices. London: Routledge.

Wieviorka, Michel. 2014. "A Critique of Integration." Identities 21 (6): 633-641. https://doi.org/10.1080/10702 89X.2013.828615

Williams, Linda M. 2015. "Beyond Enforcement: Welcomeness, Local Law Enforcement, and Immigrants." Public Administration Review 75 (3): 433-442. https://doi. org/10.1111/puar.12335
Williamson, Abigail. 2018. Welcoming New Americans? Local Governments and Immigrant Incorporation. Chicago: University of Chicago Press.

Wiginton, Lindsay. 2013. Canada's Decentralised Immigration Policy through a Localized Lens: How Small Communities are Attracting and Welcoming Immigrants. Rural Development Institute, Brandon University. Retrieved from https:/www.brandonu.ca/rdi/ files/2015/09/Canadas_Decentralized_Immigration_Policy_ How_Small_Communities_are_attracting_and-welcoming Immigrants.pdf.

Zapata, Ricard, and Fiona Barker. 2014. "Multilevel Governance of Immigration in Multinational States: 'Who Governs?' Reconsidered.” In The Politics of Immigration in Multi-level States, edited by Hepburn Eve and Richard Zapata-Barrero, 19-40. London: Palgrave Macmillan.

Zapata, Ricard, Tiziana Caponio, and Peter Scholten. 2017. "Theorizing the 'Local Turn' in a Multi-level Governance Framework of Analysis: A Case Study in Immigrant Policies." International Review of Administrative Sciences 83 (2): 241-246. https://doi. org $/ 10.1177 / 0020852316688426$ 